Przegląd Badań Edukacyjnych Educational Studies Review

ISSN 1895-4308

nr 32 (1/2021), s. 193-203

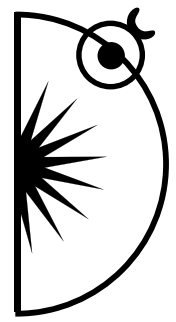

Zbyszko Melosik

ORCID: https://orcid.org/0000-0002-7802-3152

Adam Mickiewicz University in Poznan, Poland;

e-mail: zbymel@amu.edu.pl

\title{
There Is No End of Paradigms War in Social Sciences: A Meta-Analytical Approach
}

http://dx.doi.org/10.12775/PBE.2021.011

\begin{abstract}
The article is devoted to analyzing the present relevance of paradigms war concept, the most abstract meta-problem in social science. The main problem can be expressed in the following way: is it possible that there is the end of phenomenon called a paradigms war in the situation of common acceptance of pluralist approach to making science and growing importance of "mixed methods research"? To answer this question, the Author confronts the positivist and constructivist paradigms. These are compared with the special emphasis put on the epistemological differences between them and also differences between the nature of their research, quantitative or qualitative. The next analysed context is related to an alternative approach, pragmatism which rejects "the either-or position" and stresses the importance of mixed methods research is examined. To answer the main question, the Author further moves on to study these paradigms as an instrument of power in academia, especially when relating to promoting the younger generation of scholars. Against this background, the concept of epistemic communities, which is based on the idea of intersubjectivity and reciprocity of perspectives, is taken into account. Finally, the author concludes that the idea of academic freedom as a base of paradigmatic pluralism needs to be stressed. The meta-analytical approach to the main problem has been used by the author.
\end{abstract}

Keywords: paradigms, positivism, constructivism, pragmatism, power, epistemic communities, academic freedom. 


\section{Introduction}

Millions of scholars in social sciences are passionately engaged in research, studying, writing and publishing. They devote their intellectual and emotional energy to science (Barbalet, 2002). But they do not always reflect on the essential philosophical or even methodological issues that are at the core of their field of research, of all research. They conduct research without a deeper reflection on their "nature" and essential meta-assumptions. Of course, this does not mean that there is "bad research" or that all research in social science must be accompanied by philosophical considerations.

On the other hand, we cannot forget that all research, even if the researcher is not aware of it, or is not interested in it, is anchored in epistemological and ontological issues. It is not possible to imagine socializing the younger generation of scholars without providing them with awareness of a broader and deeper sense of their scientific activity. In this article, the author wishes to bring awareness of the most current abstract meta-problem in social science, which relates to the concept of paradigms and paradigms war.

\section{Paradigms and paradigms war}

The concept of paradigms war has dominated the debate in social sciences since the last decades of the 20th century. It resulted from the demise of rather absolute previous dominance of positivist research and from emerging various forms of research based on social constructivism. The aim of my paper is to analyze the present relevance of paradigms war concept. Does the paradigms war still exist? Or maybe we live in peaceful coexistence of paradigms, and this concept is quite obsolete?

I do not want to discuss here the detailed definition of paradigm. But certainly, paradigms differ in their worldview and in assumptions referring to the possibility of researching the world. For the purpose of this article, a paradigm can be described as "a set of propositions that are held and shared by members of an academic area of study to be self-evident about the nature of truth and scientific knowledge in their discipline" (Boukezzoula, 2019, p. 453).

In the positivist paradigm, reality is treated as a single entity, and there is a dualism between researchers and the objects researched. Also, there is an assumption about the possibility of "time and context-free generalization", as well as "causal linkages". It is assumed that "inquiry is value-free" (Maree, 2020, p. 24). It is based on objective observation and on various methods of measure- 
ment. From the perspective of a positivist paradigm, one can find the truth about reality (Sousa, 2010).

On the other hand, "social constructionists reject the positivist view that society can be studied objectively. Social science itself is socially constructed, they argue, so social scientists can only study society through their own set of social beliefs (...) Constructionists claim that values are an integral part of social science. It is not possible to conduct value-free social scientific research" (Hall, 2008, p. 54). Constructivists "argue that knowledge does not discover a preexisting, independent, real world (...)" (Schwandt, 1994, p. 131). So here, the truth is always socially constructed. And in a consistent constructivist approach, there are myriad forms of truths, and there are no criteria of evaluation which of them is "truer" than the other (Kukla, 2000).

From a philosophical point of view, or at the level of "meta-theoretical assumptions" at "the heart" of the paradigms war ", there is a conviction about the paradigms incompatibility" (Bryman, 2008, p. 14). Researchers cannot be simultaneously part of researched reality and be outside of it to find the truth about it. Indeed, the truth cannot be simultaneously "objective" and "subjective". The idea of "paradigms purity" is stressed here; Egon G. Guba states, "that one paradigm precludes the other "just as surely as the belief in a round world precludes the belief in a flat one" (Tashakkori \& Teddlie, 1998, p. 11). So, paradigms by their nature are in a permanent war, especially that criteria of paradigms evaluation are always a part of the paradigms. It is stated, "that different positions are incommensurable as there is no neutral ground they can use to relate to each other and be assessed" (Romani et al., 2011, p. 434).

It is worth adding that the category of "paradigms wars" is often used to explain various conflicts or collisions outside of the academia. For example, Lia Laor analyzed the first half of 19th century piano pedagogy in her book and contended that "it was governed by a conceptual framework consisting of two [struggling] paradigms - mechanistic and holistic - which emerged, respectively, from the Enlightenment and Romantic philosophies" (Laor, 2016, p. XV). And, for example, John Hudson and Stuart Lowe show paradigms war in policy evaluation research where there is a strong clash between summative quantitative "classic rational approach" and formative qualitative approach based on constructivism (Hudson \& Lowe, 2009, p. 272).

\section{The issue of methodologies}

While considering the essence of paradigms war, strictly methodological issues must also be taken into account. Mohammed Boukezzoula writes: "A methodo- 
logy is, then, a practical, coherent framework developed based on the assumptions about reality, scientific truth and the way to reach this truth stipulated by a particular paradigm. This framework governs the choice of a method. Quantitative and qualitative methodologies represent the most fundamental distinctions (...)" (Boukezzoula, 2019, p. 454). So, a methodology is "dictated by the ontological and epistemological positions of a particular paradigm. Therefore, the selection of a paradigm guides the choice of methodology, which, in turn, guides the decision about the method or methods of data collection" (Boukezzoula, 2019, p. 454). Alan Bryman even says that: "The paradigms war in this sense center on the contrasting epistemological and ontological positions that characterize quantitative and qualitative research (...)" (Bryman, 2008, p. 13). In contrast to proponents of quantitative research, who tend to find the truth about reality ,in general, qualitative research is based on a relativistic, constructivist ontology which posits that there is no objective reality" (Krauss, 2005, p. 760).

The proponents of a positivist paradigm and quantitative research stress their conviction that constructivism and qualitative research do not have any quality. They criticize qualitative research for lack of scientific standards and lack of validity. They accuse advocates of qualitative research of only being storytellers who do not contribute in any way to the progress of knowledge and science. It is also critically stressed that results of qualitative research are "random" and can never be generalized; they are "journalistic" (Holloway, 2005, p. 275). Also, often qualitative research is criticized for being subjective (Stanley \& Nayar, 2015, p. 8).

On the other hand, the positivist paradigm is criticized by opponents of quantitative research. There is an obvious point here: assumed objectivity of quantitative approach is total fiction. As Jenny E. Symonds and Stephen Gorard write: "there is a misconception among social scientists that statistical analysis is somehow a technical, essentially objective, process of decision-making, whereas other forms of data analysis are judgement based, subjective and far from technical" (Symond \& Gorard, 2008, p. 5). However, even "most closeended data is a subjective measure of subjective phenomena! (...) Personal judgment is at the heart of all decisions that we make as researchers - in our choice of research questions, samples, questions to participants and methods of analysis - no matter whether the research is numerically based or is made up of word, audio or visual data" (Symond \& Gorard, 2008, p. 5). So, from a constructivist point of view, objective science is not possible at all. A quantitative approach only pretends to be objective. 
However, recently a new approach has been developed in social sciences. Sometimes it is even called the third paradigm: mixed methods research (Johnson \& Christensen, 2012, p. 31). I do not think the name "paradigm" is proper here. I would agree with these authors who call it pragmatism. Pragmatists reject dualism objectivity/subjectivity and knower/known. They are convinced that 'scientific inquiry is not 'formalistic' and that researchers may be objective and subjective in epistemological orientation over the course of studying research question. In this case, it is more reasonable to think of a continuum than two opposing poles: At some points, one may be more 'subjective', while at others more 'objective"” (Tashakkori \& Teddlie, 1998, p. 26). Abbas Tashakkori and Charles Teddlie write about it in the following way: "On a philosophical level, pragmatists had to counter the incompatibility thesis of the paradigms warriors, which was predicated upon the link between epistemology and method" (Tashakkori \& Teddlie, 1998, p. 12). So, usually a "pragmatist position (...) ignores paradigmatic differences between quantitative and qualitative research" (Bryman, 2008, p. 19).

When we accept the pragmatist approach to research, the paradigms war seems to be over. Pragmatists dismiss the paradigms differences and propose, as I mentioned above, mixed methods research; it is sometimes called methodological eclecticism. They assume that both qualitative and quantitative research are reliable and let the researcher gather different data with the use of different methods. "The term "mixed methods research " tends to be used to represent the mixing of research methods that cross the quantitative-qualitative divide" (Bryman, 2008, p. 15). Abbas Tashakkori and Charles Teddlie write about pragmatists as pacifists, which in practice stresses the compatibility of qualitative and quantitative methods; they "adopted the tenets of paradigms relativism, or the use of whatever philosophical and/or methodological approach works for the particular research problem under study" (Tashakkori \& Teddlie, 1998, p. 5).

The pragmatists reject "the either-or position" or "incompatibility thesis" (Johnson \& Christensen, 2012, p. 31). They state that "the problem of incompatibility thesis is failure to recognize that creative and thoughtful mixing of assumptions, ideas, and methods can be very helpful and offers the third paradigm" (Johnson \& Christensen, 2012, p. 31). Believers in mixed methods research "view the use of only quantitative or only qualitative research as limiting and incomplete for many research problems" (Johnson \& Christensen, 2012, p. 35).

"In this approach, researchers use different techniques at the same time or one after another. Thus, it is possible that to transform from qualitative to the quantitative approach and vice versa (...)" (Mukherjee \& Kamarulzaman, 
2016, p. 46). Jenny E. Symonds and Stephen Gorard assume that pragmatists "focus rather on the quality of our actual research techniques, the resulting data and on how that data is used, no matter whether this involves one or more sets or types. We could use the word 'quantitative' to refer only to the activity of quantification, and 'qualitative' to describe that which is examined in-depth without being linked to a research paradigm" (Symonds \& Gorard, 2008, p. 17). Pragmatists do not consider philosophical issues which are related to paradigms war; they concentrate on "technical decisions about the appropriateness of these methods for answering research questions" (Bryman, 2008, p. 19). Proponents of the pragmatism approach see "research as using whichever research methods are most appropriate regardless of the supposed epistemological location" (Bryman, 2008, p. 20). Dawid L. Morgan calls pragmatism a "paradigm of choices" and considers this "description (...) particularly appropriate for mixed methods research because of complexity of the choices involved in integrating qualitative and quantitative methods" (Morgan, 2014, p. 8).

Pragmatists agree that "at the epistemological and ontological levels, there is an incompatibility of what should be regarded as acceptable knowledge" (Bryman, 2008, p. 15). But they assume that paradigms differences are not important in the light of concrete certain research. "At the technical level, the differences are more to do with the character of the data generated by the research methods associated with quantitative and qualitative approaches and their relevance to different kinds of research questions or roles in the overall research process" (Bryman, 2008, p. 15). So, they expose the concept of complementarity: "Each method (i.e. qualitative or quantitative) can uniquely explore different aspects of phenomenon" (Ghosh, 2020, p. 1550). Pragmatism combines an "objective" with a "subjective" approach.

Does the pragmatist approach contribute to the end of the paradigms war, or is it rather a kind of philosophical/methodological hypocrisy? At the paradigm or philosophical level, qualitative and quantitative research will be always contradictory. It must be always considered in the light of dichotomy either/either. I will repeat once more: we cannot say simultaneously that there is an ultimate truth about the world, which can be reached by quantitative methods and that there are many "equivalent truths" achieved by qualitative methods. One cannot be objective and subjective at the same time. You cannot escape the paradigm/ philosophical issue reducing problem do strictly methodological choices. The difference between qualitative and quantitative is never a solely methodological one. Methodology is always anchored in epistemology and ontology. Steven Eric Krauss says that "the heart of quantitative-qualitative 'debate' is philosoph- 
ical, not methodological. Philosophical assumptions or a theoretical paradigm about the nature of reality are crucial to understanding the overall perspective from which the study is designed and carried out" (Krauss, 2005, p. 759).

Further, we could state that it is no possible to escape the paradigm debate. By using the "mixed methods research", you can only pretend that you solve it. Pragmatism cannot be treated as a meta-paradigm; it is just... pragmatism. So, the paradigms war can never be over, although we can suspend it temporarily for particular research aims, and in this case, we can use the mixed methods approach. Mixed methods research must be situated in two paradigms simultaneously. However, it does not transcend fundamental differences between paradigms or does not question paradigms wars.

\section{Paradigms and power in the world of academia}

Paradigms (and paradigms wars) are not only the concepts; they create a scientific reality. And more over, they are an instrument of power in the academia, especially in the field of promoting the younger generation of scholars.

Science is a competitive profession (Collins, 1968, p. 128). Professors compete for prestige and reputation. In this context, the most important factor in the academia, at least in social science and humanities, is the power of defining what is scientific truth and what is excellence in scholarship. Randall Collins writes: "Intellectual consensus is undoubtedly the product of social control within the scientific community" (Collins, 1968, p. 126). The representatives of certain paradigms try to impose their assumptions on the whole community as an obligatory, as a standard of truth. And very often, the paradigm is the source of criteria used in the process of academic promotion. "What is at stake is, in fact, the power to impose the definition of science (i.e. the delimitation of the field of the problems, methods and theories that may be regarded as scientific)" (Bourdieu, 1975, p. 23).

From the post-structuralist point of view, various versions of socially constructed knowledge "fight" in the academia in order to gain the status of "normal", "true", or "universal" knowledge. They aimed to be perceived as a real science and definitely tend to exclude alternative versions. Their believers depreciate alternative knowledge as deprived of scientific value. And they treat their own knowledge as "the only representative", "all-embracing", "total", and "overall" (Melosik, 2009, p. 56). This knowledge, anchored in a certain paradigm, is seen as an ultimate criterion of explanation. So, the believers in the paradigm and the theories that result from it try to create a canon of knowledge and Great Books, which epitomize their views (Melosik, 1996, p. 29). 
However, it often appears that new socially constructed forms of knowledge and new theories try to question the domination of the canon, or at least to become an integral part of it. Progress in humanities and social sciences is not an essentialist concept. It is a social construction itself, a result of a game of knowledge and a game of truth. And one of the most important forms of creating the regime of truth is the process of academic promotion, which has been mentioned above.

Finally, the author wishes to emphasize that he does not accept the idea of the end of the paradigm war, as he truly agrees with the conviction that "the two approaches could not be used together because of differences in the worldviews or philosophies associated with the two approaches" (Johnson \& Christensen, 2012, p. 31). Next, in the context of academic promotion, it is important to refer to the concept of an epistemic community. In various definitions of epistemic community, the concept of truth, objectivity, or universal knowledge is not stressed. According to Elizabeth Bloodgood, the members of the epistemic community accept "a shared set of normative beliefs around which a community begins to crystalize" (Bloodgood, 2008, p. 9). "Theories and evidence which accord with prevailing norms are accepted as [validated] knowledge" (Bloodgood, 2008, p. 8). Andrea Bonaccorsi writes: "By 'epistemic' I mean the way by which scientific communities produce valid knowledge, or the procedures, criteria, practices by which they recognise intersubjectively the value and validity of knowledge (...)" (Bonaccorsi, 2018, p. 1). Peter M. Haas states that members of the epistemic community have "common notion of validity: intersubjective, internally defined criteria for validating knowledge (...)" (Haas, 2015, p. 5). Epistemic communities' activity is based on the idea of intersubjectivity, which "assumes reciprocity of perspectives" (Grinnell, 2009, p. 15). And this could be a source of values and evaluation in a particular research community.

Certainly, the concept of an epistemic community does not solve the problem of the paradigms war. It even does not try to do so. It relies on the wisdom of the community of scholars. The paradigms war continues, although in a more silent way than it has used to be in the past. But growing acceptance for heterogeneity and pluralism of research in academia lets scholars find their own place in the world of research.

\section{Conclusion}

Finally, it is relevant to concentrate attention on the concept of academic freedom. At its core, there is a conviction about a necessary autonomy of the uni- 
versity from politics and economy. In addition, it is imperative to stress another dimension. The most integral part of academic freedom is related to having, preserving and deepening the disposition to freedom of thought and freedom of thinking, irrespective of the outer conditions. So, I am convinced that the most important source of academic freedom is socializing the young scholar into freedom of thinking as a ground of their scientific identity. Such freedom is not only the basis of creative intellectualism. It also lets the scholar slip away from outer pressures and limitations. Freedom of thinking allows for the development of permanent critical distance towards one's own thinking and the intellectual courage to question one's own intellectual schemes of doing science, including paradigmatic assumption (Melosik, 2019). It also allows a scholar to accept the existence of contradictory paradigms while working within his/her own one.

\section{References}

Barbalet, J. (2002). Science and Emotions. Sociological Review, (50)2, 75-96. doi: 10.1111/j.1467-954X.2002.tb03595.x.

Bloodgood, E. (2008). Epistemic Communities, Norms, and Knowledge, San Francisco: Paper prepared for presentation at the International Studies Association Annual Conference. Retrieved 27 October 2020 from http://citeseerx.ist.psu.edu/viewdoc/download?do$\mathrm{i}=10.1 .1 .701 .9474 \& \mathrm{rep}=$ rep $1 \&$ type $=$ pdf.

Boukezzoula, M. (2019). A Plea for a Focus on the Contrasts Between Two Paradigms and Their Implications for Problem Statement. Arab World English Journal, (10)3, 448-469, doi: 10.24093/awej/vol10no3.32.

Bonaccorsi, A. (2018). Towards an Epistemic Approach to Evaluation in SSH. In: A. Bonaccorsi (Ed.), The Evaluation of Research in Social Sciences and Humanities. Lessons from the Italian Experience (pp. 1-29). Cham: Springer, doi: 10.1007/978-3-31968554-0_1.

Bourdieu, P. (1975). The Specificity of the Scientific Field and the Social Conditions of the Progress of Reason. Social Science Information, (14)6, 19-47, doi: $10.1177 / 053901847501400602$.

Bryman, A. (2008). The End of Paradigms War? In: P. Alasuutari, L. Bickman, \& J. Brannen (Eds.), The Sage Handbook of Social Research Methods (pp. 13-25). Los Angeles: Sage Publications, doi: 10.4135/9781446212165.n2.

Collins, R. (1968). Competition and Social Control in Science: An Essay in Theory Construction. Sociology of Education, (41)2, 123-140, doi: http://dx.doi.org/10.2307/2111847. 
Ghosh, R. (2020). Mixed Methods Research: What are the Key Issues to Consider? In: M. Khosrow-Pour (Ed.), Cognitive Analytics: Concepts, Methodologies, Tools, and Applications (pp. 32-41). Hershey: IGI Global, doi: 10.4018/978-1-7998-2460-2.ch079.

Grinnell, F. (2009). Everyday Practice of Science: Where Intuition and Passion Meet Objectivity. Oxford: Oxford University Press, doi: 10.1093/acprof:oso/9780195064575.001.0001.

Haas, P.M. (2015). Epistemic Communities, Constructivism and International Environmental Politics. London: Routledge, doi: 10.4324/9781315717906.

Hall, R. (2008). Applied Social Research: Planning, Designing and Conducting Real-World Research. South Yarra: Palgrave MacMillan.

Holloway, I. (2005). Qualitative Writing. In: I. Holloway (Ed.), Qualitative Research in Health Care (pp. 270-286). Maidenhead: Open University Press.

Hudson, J., \& Lowe, S. (2009). Understanding the Policy Process: Analysing Welfare Policy. Bristol: The Policy Press.

Johnson, B. \& Christensen, L. (2012). Educational Research: Quantitative, Qualitative, and Mixed Approaches. Los Angeles: Sage.

Krauss, S. E. (2005). Research Paradigms and Meaning Making: A Primer. The Qualitative Report, (10)4, 758-770, doi: 10.46743/2160-3715/2005.1831.

Kukla, A. (2000). Social Constructivism and the Philosophy of Science. London: Routledge, doi: 10.4324/9780203130995.

Laor, L. (2016). Paradigm War: Lessons Learned from 19th Century Piano Pedagogy. Newcastle: Cambridge Scholars Publishing.

Maree, D. J. F. (2020). Realism and Psychological Science. Cham: Springer, doi: 10.1007/9783-030-45143-1.

Melosik, Z. (2019). Pasja i tożsamość naukowca. O władzy i wolności umystu [Passion and Scientist Identity. On Power and Freedom of Mind]. Poznań: Wydawnictwo Naukowe UAM.

Melosik, Z. (2009). Uniwersytet i społeczeństwo. Dyskursy wolności, wiedzy $i$ władzy [University and Society. Discourses of Freedom, Knowledge and Power]. Kraków: Impuls.

Melosik, Z. (1996). Tożsamość, ciało i władza. Teksty kulturowe jako (kon)teksty pedagogiczne [Identity, Body and Power. Cultural Texts as Pedagogical (Con)Texts]. Poznań-Torun: Wydawnictwo Edytor.

Morgan, D.L. (2014). Integrating Qualitative and Quantitative Methods: A Pragmatic Approach. Los Angeles: Sage. 
Mukherjee, A., \& Kamarulzaman, N. H. (2016). Mixed Method Research: A Concept In: M. L. Baran, \& J.E. Jones (Eds.), Mixed Methods Research for Improved Scientific Study (pp. 39-65). Hershey: IGI Global.

Romani, L., Primecz, H., \& Topçu, K. (2011). Paradigm Interplay for Theory Development: A Methodological Example With the Kulturstandard Method. Organizational Research Methods, 14 (3), 432-455, doi: 10.1177/1094428109358270.

Schwandt, T.A. (1994). Constructivist, Interpretivist Approaches to Human Inquiry. In: N.K. Denzin, \& Y.S. Lincoln, Handbook of Qualitative Research (pp. 118-137). Thousand Oaks: Sage Publications.

Sousa, F. J. (2010). Metatheories in Research: Positivism, Postmodernism, and Critical Realism. In: A.G. Woodside (Ed.), Organizational Culture, Business-to-Business Relationships, and Interfirm Networks (pp. 455-503). Bingley: Emerald Group Publishing Limited, doi: 10.1108/S1069-0964(2010)0000016012.

Stanley, M., \& Nayar, S. (2015). Deepening Understandings. In: S. Nayar, \& M. Stanley (Ed.), Qualitative Research Methodologies for Occupational Science and Therapy (pp. 8-20). Abingdon: Routledge.

Symonds, J. E., \& Gorard, S. (2008). The Death of Mixed Methods: Research Labels and their Casualties, Heriot Watt University, Edinburgh: The British Educational Research Association Annual Conference. Retrieved 10 October 2020 from https://www.researchgate.net/publication/252477890_The_Death_of_Mixed_Methods_Research_Labels_and_their_Casualties.

Tashakkori, A., \& Teddlie, C. (1998). Mixed Methodology: Combining Qualitative and Quantitative Approaches. Thousand Oaks: Sage Publications. 